\author{
Amara Moira Rodovalho \\ Universidade Estadual de Campinas, SP, Brasil
}

\title{
CIS by TRANS
}

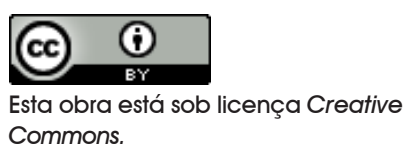

Commons.

\section{Preamble}

Cis, trans: above all, metaphors. Cisjordan, region skirting the Jordan River. Cisplatin, Uruguay's ancient name, region occupying one of the banks of the Prata River. TransAmazonian, that which crosses the Amazon; transatlantic, that which crosses the Atlantic. Cisalpine, transalpine. The geometric isomerism of Organic Chemistry, where "cis" are atoms that, when molecules are divided in half, remain on the same side, and "trans" those remaining on opposite sides. Even the Houaiss dictionary, presenting the cis etymology as "from the Latin preposition cis 'below, on this side' (in opposition to trans)". And many other examples. Metaphors, always metaphors. Something that crosses, trespasses, goes through and something that remains always on the same side, skirting, not crossing, that avoids crossing, all in relation to a given line. Can we imagine the use of one of these terms without, immediately, referring to the other? From this rhetorical question, I dare to claim that medical discourse, by naming as "trans" our peculiar way of living, of claiming existence, has automatically named the other way, its way, non-trans, as "cis", leaving to us only the task of thinking ways of making the two images proposed, something-that-crosses and something-that-avoids-crossing, translate themselves into more tangible meanings.

In regards to the debate of gender identities, however, "cis" emerges only seventy years after the term opposing it, "trans", the latter in the 20's, the former almost at the turn of the 21 st century, and we can understand this delay. There are few registers in history of people who, in the distant past, claimed an existence other than the one predicted by their genitals. The truth is, in a deeply cissexist society, a society so cissexist that cannot even perceive its own cissexism (so deeply naturalized this unspoken law was, with its origin, its reason 
erased), there would be no possibility of thinking the concrete, material existence of trans people. Due to transphobic violence, deeply grounded in sexism, those people daring to defy this law would be killed or immediately return to the closet, giving the false impression that they did not exist in the first place or that they unexisted. The rise and growth of the feminist movement, with its radical transformation of the meanings the word "woman" denotes, was necessary for people raised to be men to start, little by little, claiming their legitimate right to exist as women and, nowadays, people raised to be women start to make their claim to exist as men reasonable and acceptable (the fact that only recent the idea of trans men is becoming familiar, intelligible, demonstrates how our society treats people raised to be women).

In light of this short overview, which does not have the objective of being strict or even accurate, when one voices dislike for the term "cis", for being reductive, the first thing that comes to me is finding out how the person in question understands and develops this term. The answer I often receive does not substantially differ from "a person who identifies with the gender assigned at birth", or something very similar. We can see that the emphasis in identification, in selfidentification, shifts the discussion I am proposing here from the political, social realm to the individual, subjective aspect, something we have less access to. I am able to see trans people and even cis people walking on the streets, but I would rarely have access to what they think about themselves and/or how they identify themselves: I would access, at best, what they say about themselves, which is not the same thing, unless we believe the person knows exactly what he/she is, and is able to say it clearly, aside from the fact of actually wanting to say it. Back to that answer concerning the term "cis", what is interesting is that such identification, regarded as reductive by that $X$ person (which happens to be cis in $99.9 \%$ of the cases) to whom I am talking to, also demonstrates what the person in question understands as "trans" - "a person who does not identify with the gender assigned at birth" - an understanding that, I dare say, is equally narrow; yet such narrowness does not allow this $X$ person to feel entitled (or compelled?) to attack the inadequacy of the concept, placing the responsibility on our shoulders. Well, the same people who refuse to use "cis" often use the term "trans", and they use it because they believe this term means something, even if they cannot explain exactly what it means. They use it because they believe we exist, and they believe we exist because they can no longer pretend we don't, they cannot pretend to not see us amid the crowd.

That is the point: we exist, we could easily say. When the "not-us" became aware of this fact, they thought up a 
metaphor to explain our existence, our condition, being this metaphor an implicit projection of an image of what we are not, of what we have stopped being, of what would be this not-us naming us as "trans". Then, this not-us sought verbal formulations to unravel the "trans" metaphor, and such formulations never did justice to the multiplicity of existences encompassed by this metaphor, an insufficiency which, as we make ourselves visible and demand respect, becomes less and less a valid argument to defend our nonexistence. Again, that is the point: we exist, and we do so because of this "not-us". And, if we exist, being even entitled to a name, maybe people who are not us (and from whom we received the name "trans") would also need a name, not one to grant them existence (after all, who would doubt that, due to being nameless, they do not exist?), but one to make explicit the reason why they defined us as those who cross, trespass (deceive?), transgress a certain line, namely, the line separating men from women. Naming what is non-trans, notus, emerges from a very particular necessity of understanding with increasing clarity that the insufficiency of what people say we ought to be has to do, above all, with the refusal of locating themselves, of saying who they are when talking about us, considering that these are the people who mostly talk about us, on our behalf: if we name them "cis", it is to better understand the view of those who first granted us existence, the view that, nowadays, is starting to allow us to exist.

In the beginning, one hundred, fifty years ago, when we existed only to mental health professionals, in their clinics and mental institutions, the emphasis in self-identification made perfect sense. Occupying the streets, existing beyond these spaces, was not an option, thus the only way to make ourselves aware was through these timid, lamenting testimonies. We passed for insane people and, perhaps due to the very impossibility of existing and the repression we constantly suffered, we were: society rendered us ill and maybe it is about time for it to recognize its role in our madness, its accountability for not being able to make us into what it created us to be. Our right to, as they would call, "cross" such line dividing gender starts to take shape only as we give legitimacy to the testimony explaining this desire: if an explanation was necessary, then the focus on selfidentification would give all answers, and together with this awareness, we would win the right to start to exist in another gender, not only for ourselves, but also for a broad community. Today, we have a different situation. There is a substantial number of us walking on the streets, occupying public spaces. We can say for sure that most of us are being harassed and killed, excluded from most spaces, and yet 
one cannot deny we exist in our plenitude, once it is difficult to find people who do not know about our existence.

Self-identification is still important for fighting the demonization of the choice to cross the line, the choice to yield to this impulse and move beyond what we were raised to be (if there was not at least a little choice, there would be no closet either), but today we have much more than this testimony, this self-identification in order to think trans existences. Moreover, one cannot forget that in most social interactions there is not enough time to state what you are, and your body must necessarily transmit the message in the most unambiguous way: this does not mean, absolutely, that we effectively subject ourselves or that we should subject ourselves to cis stereotypes, mimicking those to perfection in order to demand any respect or to be left alone, but rather that there is a large investment in the construction of this body, a body that is also an identity, in order to lighten the burden of negotiating with others whatever we are or are not. One yields to this stereotype just as much as it is perceived as meaningful, trying to minimize the distress and the harassment of others delegitimizing our existence: that is the idea. It works in this way due to identity, our role in this world, not being decided by decree, but a criticism to this blinding focus on self-identification: identity requires identification with someone, but this identification is not one-sided, "your word against mine", "your word is enough". The group we identify with will have to at least recognize the legitimacy of our identification (as well as that of other social actors), otherwise what we have to say about us, about what we are, will be rendered useless.

This struggle does not consist merely in gathering a maximum of cis stereotypes in order to be able to pass and remain unseen in the crowd, preserving yourself from transphobia; it means giving legitimacy to the discourse that acknowledges trans womanhood as part of the notion of womanhood itself and trans manhood as part of full manhood, rearranging the meanings of the words "woman" and "men". People will continue to read us as trans, they will increasingly see us walking on the streets, but now, when they come across us, they will understand what we are trying to convey through our bodies and will also see in us a reflection of what they did not allow themselves to be. The focus on self-identification reinforces the idea that only whatever crosses the line requires an explanation, not what doesn't, what avoid crossing. Should one cross or avoid crossing? This doubt may seem uncalled for, but the second phrase sheds light on the extent of choice in this "not-crossing", how much this "not-crossing" might be due to our society's transphobic nature - the world seen through our eyes. However, 
in either phrase we get the impression that those who "do not cross" / "avoids crossing" are not skirting the line or following it somehow, but remaining static, motionless, petrified, before our audacity of crossing: could this be the uneasiness they feel when seeing themselves under the "cis" sign?

Cis: the opposite of trans, whatever this means. If "cis" seems a narrow concept, it is a sign that your own understanding of "trans" is also narrow.

\section{Cis women, travestis and trans men}

Let's picture that line dividing men and women and recall Beauvoir's "one is not born a woman, but becomes one". Certainly, biology is not responsible for one's womanhood, but we know that this person's genitalia, perceived as "female" at birth, will cause this person, this $X$ person, to be raised to be a woman, which will mean both that she will understand herself as woman and make herself intelligible as such to society (to "look like a woman" is the foundation for "being a woman": any trans person who is perceived as cis will be safe from transphobia whenever this perception is not put to test, while the cis person perceived as trans will suffer transphobia even if he/she does not conceive him/herself as trans). If in the course of this process, the person raised to be a woman understands him/herself to be one, claiming to be and be perceived as a woman, he/ she will be at the "woman" side, always skirting the invisible line dividing gender, even if he/she flirts with what lies beyond the line. If this other person, however, claims for him/herself an existence other than the one he/she was raised as, i.e., in this case, the existence of a man, then this person will be a trans man. Cis and trans are points of reference, two extremes of a given world division, among which there is a great diversity of subjects, sometimes blurring the lines.

As previously posited, self-identification is insufficient to solve the problem, once people's role in the world is not decided unilaterally, by decree, but through a tense negotiation of meanings between what is and what seems to be. How should we name the violence when masculine women (and I would rather use "masculine" instead of "masculinized", as the suffix "-zed" gives an impression of something spurious) are victim of discrimination due to a failure in performing femininity? We could think of lesbophobia, believing the abuser has imagined that she is, or perhaps she made herself into, masculine due to "liking women", but before "liking women" (which may even not be the case) there is something "she made herself into", something "she is", which is considered much more evident or aggressive in our misogynistic and sexist culture. No wonder 
trans men took much more time to make themselves known and intelligible, to organize themselves in a political movement claiming their rights, presenting their agenda. Would cases of cis women expelled from female bathrooms for being perceived as cis men also be cases of lesbophobia, always and unmistakably lesbophobia? I doubt that a person perceived as a trans man, i.e., as a man with vagina, as a person raised to be woman but who refused to accept and fit into this fate, would be expelled, a fact that clearly illustrates the problem between what one is and what one seems to be.

We thus return to the insufficiency of self-identification. We can focus on what people claim to be (or think they claim to be, once there is the unconscious and also this language which resists saying what we want it to say - think, for example, the amount of times we use the expression "that was not what ( meant") or, instead, try something more palpable than discourse itself, something more visible, more sensible, the sheer manner these people exist. If we ask transvestites what they are, they answer may vary: 1) "I am a woman, right?"; 2) "well, if you were born with a penis, you are a man, there is nothing to do about it" and 3) "neither woman or man, I am a transvestite". If we based our thoughts on what they say, on what they are capable of saying about themselves, it would be impossible to find a way of placing them in society and of defining their roles. This variation is due, among other things, to the fact we do not raise anyone to be a transvestite: Beauvoir's "one is not born, but becomes" takes a very particular meaning when we talk about this category, as the option "born" is inexistent for us, only the option "to become". Does it make any difference if transvestites identify themselves as "men" or "women" when it comes to the violence they are subject to? Would they be exempted from being expelled from home, school, from the traditional job market, finding in the most precarious form of prostitution almost their only way to survive, would they be exempted from being brutally objectified on the streets, from having their life expectancy around thirty-five years old? No matter what they say, nothing will better convey the message of what they are and what they are not than their bodies. Because "man" and "woman" are polysemic words, containing very distinct meanings, even conflicting ones, an extreme caution is necessary when interpreting such words.

Radical feminists are right when they claim cis women are women even before having an identity, eve before being able to say what they are or what they are not. They were raised to be women and this means precisely that when they enter discourse, they must already understand themselves as women. There is no choice, they do not even know they 
are being raised as such. Therefore, their only option is to be, as they are already being raised as such, that is how it works. Women. In this sense, they are also right when they say that "being a woman" is more than a feeling, it is not selfidentification: being woman, it matters very little what they have to say about themselves, "I do not feel like a woman", "I did not want to/do not want to be a woman", once they will continue to be treated in the same manner. Identity, their role in the complex social game does not work on the basis of "I decided, that's it".

That said, it is important to notice, however, that we increasingly see a certain group of people raised to be women, i.e., born with vaginas, the so-called females, not only claiming the right of recognizing themselves as men, but also of effectively being treated as such. How does this happen? This happens precisely because identity is not decided by decree. These people, though raised to be women, at the end of this process did not understand themselves as such, and started to resist this creation, appropriating the signs which denote masculinity in order to make others perceive them as they wanted to be perceived. No one is to blame, no one has a choice. We need to understand more about language acquisition, about psychoanalysis, if we want to grasp the meaning of this "feeling like a woman" claimed by trans women and "feeling like a man" claimed by trans men. This is what we know about ourselves, those are the words available to us, the words others have taught us. We need to know how to read beyond the surface of these words. Little trans girls, when facing their upbringing, do not say "I feel like a woman", but rather "I am a woman", and she will be harassed for this reason. She will learn throughout her life that saying "I FEEL LIKE A WOMAN" can be much more effective in touching and moving others than just saying "I AM WOMAN". We play with the weapons available to us, the weapons given to us, taught to us.

Two meanings of being woman in dispute. On the one hand, the person who was compelled her entire life to fit in an oppressive model of woman, that of femininity, fragility, insecurity, dependency, of care and fear. This model, by putting women in a vulnerable position in relationto men, is necessarily oppressive, yet we cannot forget that a lot of women will find a way to grant meaning to this fate. It is important to keep this in mind to understand why children who are raised to be men from an early age will not find this imposed future, a future of much less vulnerability, and will start to claim another one, the future of the person they see themselves to be, from whom they will construct their own image, identity, the woman they identify with, the woman 
they want to see within themselves. It is not obvious to any child that in a sexist society womanhood is a prison, a form of violence, and in the same way that this information is not evident, the manner the identity of this child is being constructed is not something conscious. We need to be more careful when interpreting what we can say about our own condition, but above all we can neither lose sight that, no manner what trans people say, they are increasingly living for themselves and for others in the way they want to. We are not talking about words alone.

I end this article returning to radical feminists, a group with which the trans movement, and especially the transfeminist movement, has more disagreement and discordance, unfortunately: they seem to want to contain the polysemy of the word "woman", deny the right of every living word to acquire new meanings. I can understand why they become bothered by seeing the identity between cis and trans women being established in such an easy manner, as if it were obvious - "they are all women and end of story" without trying to understand together the way in which these two kinds of womanhood, cis and trans, come to be (issues like, for example, the role of Oedipus and Electra complexes, the coercions based on gender to compel the child to a certain role, the repetition of behaviors perceived in the first figure(s) whom the child identifies with and sees himself/herself, from whom he/she will construct his/her own identity). I can understand this uneasiness, this attempt to force an identification between groups which do not see themselves as identical [yet?], between groups which do not allow themselves common traces, but to me this normative position in regard to language, this attempt to block the new meanings the word "woman" acquires as we make ourselves visible, as we make our existence legitimate, seems untenable. I can imagine a foreseeable future when the entry "woman" in dictionaries brings, among all other possible definitions, at least one considering trans women (something like "those who, for themselves and for society, became woman, even though they were raised as men due to the genitalia they were born with") and another exempting trans men from its definition (perhaps "those who, being raised to be women due to the genitalia they were born with, exist for themselves and for society under the identity of woman").

\section{Bibliography}

BARBOSA, Lázaro. "Sobre TERFs, transfobia e imprecisões conceituais: considerações sobre um texto de Carla Rodrigues". Available in (accessed in 01/15/2016): http:/ /www.cartapotiguar.com.br/2014/12/14/sobre-terfs- 
transfobia-e-imprecisoes-conceituais-consideracoessobre-um-texto-de-carla-rodrigues/

BAGAGLI, Bia Pagliarini. "Foraclusão do termo cisgênero e a política do significante". Available in (accessed in 01/ 15/2016): http://transfeminismo.com/foraclusao-do-nomecisgenero-e-a-politica-do-significante/

BEAUVOIR, Simone de. O segundo sexo. São Paulo: Nova Fronteira, 2009, volume único.

DUMARESK, Leila. "O cisgênero existe". Available in (accessed in 01/15/2016): http://transliteracao.com.br/ leiladumaresq/2014/12/o-cisgenero-existe/

KAAS, Hailey. "O que é cissexismo". Available in (accessed in 01/15/2016): http://transfeminismo.com/o-que-ecissexismo/

RODRIGUES, Carla. "O (cis)gênero não existe". Available in (accessed in 01/15/2016): http://www.blogdoims.com.br/ ims/o-cisgenero-nao-existe

[Recebido em 12/05/2016

e aceito para publicação em 21/09/2016]

Amara Moira Rodovalho (amoiramara@gmail.com). É travesti, prostituta, doutoranda em Teoria e Crítica Literária pelo Instituto de Estudos da Linguagem/UNICAMP, feminista e militante dos direitos de LGBTs (Ts em especial) e de profissionais do sexo. Autora do blog www.eSeEuFossePuta.com.br, onde escreve de uma perspectiva literária e feminista sobre sua experiência como prostituta, obra que virou livro e que já foi objeto de estudo de duas teses de Doutorado. Integra o Grupo Identidade (LGBT), o Coletivo TransTornar (pessoas trans) e a Associação Mulheres Guerreiras (profissionais do sexo), sediados em Campinas e com forte atuação militante nas redes sociais. Foi pré-candidata (2016) a vereadora em Campinas pelo Partido Socialismo e Liberdade (PSOL). É mestra pelo IEL/UNICAMP com uma tradução crítica e comentada do livro de contos Dubliners de James Joyce, e no Doutorado desenvolve estudo sobre as zonas de indeterminação de sentido na obra do mesmo autor, e sobre a maneira como lidaram com essa indeterminação de sentido alguns de seus tradutores mais destacados. 